ENVIRONMENTAL RESTORATION PROGRAM

\title{
In Situ Modular Waste Retrieval and Treatment System
}

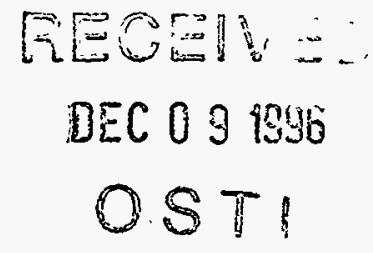

This document has been approved by the ORNL Technical Information Office for release to the public. Date: 10/23/96 


\section{Machine Kenetics Corporation}

contributed to the preparation of this document and should not be considered an eligible contractor for its review.

This report has been reproduced directly from the best available copy.

Available to DOE and DOE contractors from the Office of Scientific and Technical Information, P.O. Box 62, Oak Ridge, TN 37831; prices available from 423-576-8401 (fax 423-576-2865).

Available to the public from the National Technical Information Service, U.S. Department of Commerce, 5285 Port Royal Rd., Springfield, VA 22161. 


\section{DISCLAIMER}

This report was prepared as an account of work sponsored by an agency of the United States Government. Neither the United States Government nor any agency thereof, nor any of their employees, makes any warranty, express or implied, or assumes any legal liability or responsibility for the accuracy, completeness, or usefulness of any information, apparatus, product, or process disclosed, or represents that its use would not infringe privately owned rights. Reference herein to any specific commercial product, process, or service by trade name, trademark, manufacturer, or otherwise does not necessarily constitute or imply its endorsement, recommendation, or favoring by the United States Government or any agency thereof. The views and opinions of authors expressed herein do not necessarily state or reflect those of the United States Government or any agency thereof. 
Energy Systems Environmental Restoration Program

\title{
In Situ Modular Waste Retrieval and Treatment System
}

\author{
M. S. Walker
}

Date Issued-October 1996

\author{
Prepared by \\ Machine Kinetics Corporation \\ Knoxville, Tennessee \\ under subcontract MKC 4137 \\ Prepared for the \\ U.S. Department of Energy \\ Office of Environmental Management \\ under budget and reporting code EW 20 \\ Environmental Management Activities at \\ OAK RIDGE NATIONAL LABORATORY \\ Oak Ridge, Tennessee 37831-6285 \\ managed by \\ LOCKHEED MARTIN ENERGY SYSTEMS, INC. \\ for the \\ U.S. DEPARTMENT OF ENERGY \\ under contract DE-AC05-84OR21400
}





\section{PREFACE}

As part of the Comprehensive Environmental Response, Compensation, and Liability Act process for remediation of Waste Area Grouping (WAG) 6 at Oak Ridge National Laboratory, a public meeting was held for the Proposed Plan. It was recognized that contaminant releases from WAG 6 posed minimal potential risk to the public and the environment. The U. S. Department of Energy (DOE) in conjunction with the U. S. Environmental Protection Agency and the Tennessee Department of Environment and Conservation agreed to defer remedial action at WAG 6 until higher risk release sites were first remediated.

DOE and the regulators also recognized the need for technology development for final remediation of WAG 6. Consequently, the Record of Agreement for the WAG 6 deferred action established the WAG 6 Remedial Technology Research, Development, and Demonstration Program for the Environmental Restoration(ER) Program to develop and demonstrate innovative technologies for the final remediation of WAG 6 and other ER contaminated sites.

This report presents the results of a conceptual design for an In Situ Modular Retrieval and Treatment System able to excavate, shred, and process buried waste on site, with minimum disturbance and distribution of dust and debris. The system would bring appropriate levels of treatment to the waste then encapsulate and leave it in place. The system would be applicable to areas in which waste was disposed in long trenches. The ER-sponsored study was performed by Machine Kinetics Corporation of Knoxville, Tennessee, under Work Breakdown Structure 1.4.12.6.1.06.02. 


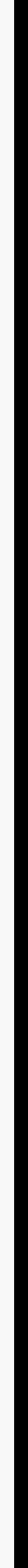




\section{CONTENTS}

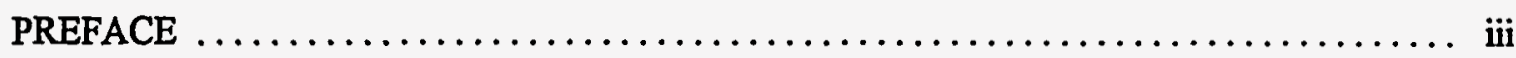

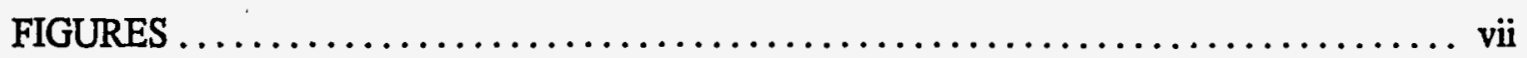

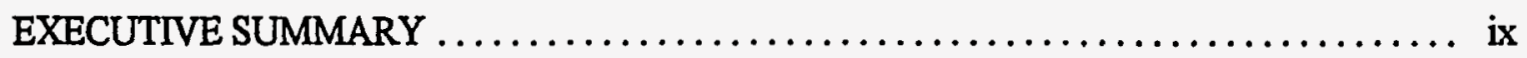

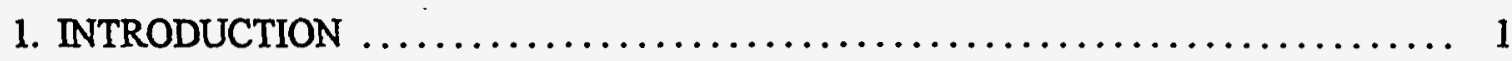

2. CONCEPTUAL DESCRIPTION $\ldots \ldots \ldots \ldots \ldots \ldots \ldots \ldots \ldots \ldots \ldots \ldots \ldots \ldots \ldots \ldots \ldots \ldots, 2$

2.1 MODULE FEATURES $\ldots \ldots \ldots \ldots \ldots \ldots \ldots \ldots \ldots \ldots \ldots \ldots \ldots \ldots \ldots \ldots \ldots \ldots \ldots, 4$

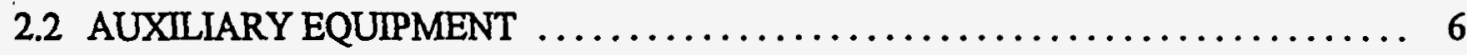

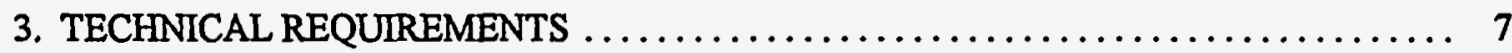

3.1 EXISTING TECHNOLOGIES $\ldots \ldots \ldots \ldots \ldots \ldots \ldots \ldots \ldots \ldots \ldots \ldots \ldots \ldots, 7$

3.2 TECHNOLOGY NEEDS $\ldots \ldots \ldots \ldots \ldots \ldots \ldots \ldots \ldots \ldots \ldots \ldots \ldots, 9$

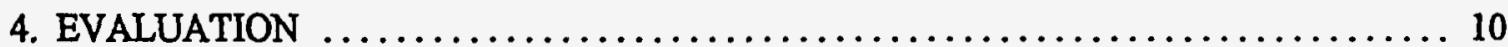

4.1 POTENTIAL BENEFITS $\ldots \ldots \ldots \ldots \ldots \ldots \ldots \ldots \ldots \ldots \ldots \ldots \ldots \ldots \ldots \ldots, 10$

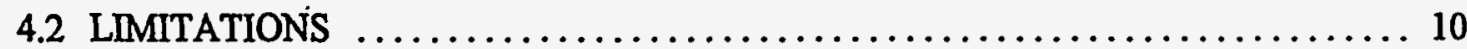

4.3 ROUGH DEVELOPMENT COST AND SCHEDULE $\ldots \ldots \ldots \ldots \ldots \ldots \ldots \ldots \ldots$

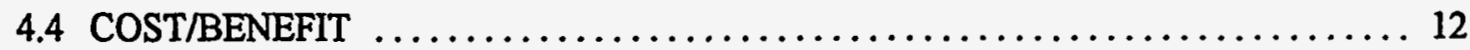

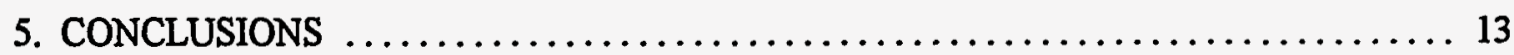

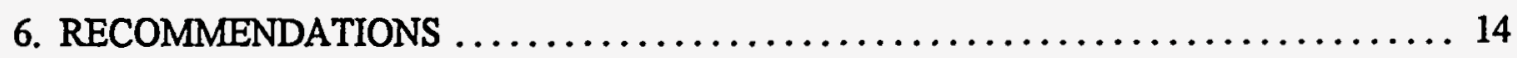

Appendix: IN SITU MODULAR RETRIEVAL AND TREATMENT

SYSTEM VENDOR AND TECHNOLOGY SOURCE LIST ............... 



\section{FIGURES}

1. In Situ Modular Retrieval and Treatment System for shallow buried waste $\ldots \ldots \ldots \ldots \ldots$. 2

2. Operation sequence of the In Situ Modular Retrieval and Treatment System $\ldots \ldots \ldots \ldots \ldots$

3. In Situ Modular Retrieval and Treatment System module arrangement $\ldots \ldots \ldots \ldots \ldots \ldots$. 5

4. In-situ retrieval and treatment system internal arrangement $\ldots \ldots \ldots \ldots \ldots \ldots \ldots \ldots \ldots \ldots \ldots$ 


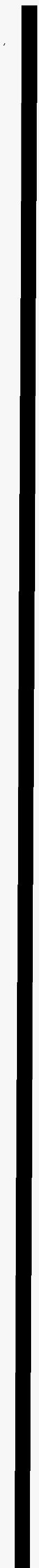




\section{EXECUTIVE SUMMARY}

This report describes a conceptual design for an In Situ Modular Waste Retrieval and Treatment System able to excavate, shred, and process buried waste on site with minimum disturbance and distribution of dust and debris into the air. The proposed equipment design consists of a modular train configuration with an excavation module followed by other units consistent with the types of waste expected and other local conditions. The system would be sized to enter a waste trench at one end and proceed down its length, characterizing and processing waste as it is encountered. The equipment would provide containment, since all waste processing activities would occur within the system, and thus would prevent the release of contaminants and the exposure of workers. The system would substantially reduce the volume of the wastes as well as the eliminate of most of its volatile contents. The system would bring appropriate levels of treatment to the waste and addresses the fact that much of the waste buried in the DOE complex does not require exotic treatment technology. In many cases a stabilized waste form and increased containment are all that is required. The processed waste would be encapsulated and left in place in the trench or moved to a more appropriate site. The system would have immediate application in areas wherever systematic burial in fairly consistently sized long trenches was practiced. The size of the system would address the problem of large landfills by providing a means for faster remediation. The system would also be very useful in existing civic or commercial sanitary landfills by performing a reduction in volume, leachate, and release of volatiles. Unit costs on the order of $\$ 300 /$ cubic yard could be achieved. While this equipment would require a very substantial capital investment, the result would certainly be competitive with current remediation costs and would achieve remediation at a rate beyond any current means. 


\section{INTRODUCTION}

The purpose of this report is to outline a concept of an In Situ Modular Retrieval and Treatment System for shallow buried waste and to make recommendations for further action on the concept. The concept is shown schematically in Fig. 1. The proposed system would consist of multiple modules designed to excavate, shred, and process the buried waste on site. The equipment would be constructed on a scale large enough to excavate and treat entire trenches with a single pass down the length of the trench. The operating mechanism would begin at the end of a waste trench and progressively excavate the trench, characterize the waste, shred the waste, process it, and discharge an acceptable waste form into the former trench location. Different unit treatment modules could be designed to handle different types of wastes. This equipment could become a very effective delivery system for a variety of existing treatment options. The equipment would consist of a modular train configuration with an excavation module, followed by other units consistent with the types of waste expected and other local conditions. The result would be a substantial reduction of the volume of the wastes as well as the elimination of most of its volatile contents. The processed waste would be encapsulated and left in place in the trench or moved to a more appropriate site. The final treatment would result in a waste form which meets Resource Conservation and Recovery Act and Comprehensive Environmental Response, Compensation, and Liability Act requirements for land disposal. This equipment is designed to bring the appropriate level of treatment to the waste. The U.S. Department of Energy (DOE) complex has sites which contain high-level or highly concentrated radioactive waste materials, but far more of the landfills contain materials which are low-level, trace contaminated, or just suspected of being contaminated. Exotic treatment methods are not necessary for these sites. In many cases, a stabilized waste form and increased containment is all the remediation the waste really needs.

The In Situ Modular Retrieval and Treatment System would provide containment. All the waste excavation, waste handling, shredding, and treatment operations would be contained within the system, and contamination would not be released. nor workers exposed. This is in sharp contrast to other approaches which are often considered for retrieval. With many approaches, there are containment issues related to every step of an excavation, retrieval, handling, and treatment processes. For example, waste trench excavations with conventional construction equipment often require temporary structures or structures on rails to prevent spread of contamination. With the In Situ Modular Retrieval and Treatment System, containment would be assured throughout the process.

The In Situ Modular Retrieval and Treatment System would have immediate application in areas wherever systematic burial in fairly consistently sized long trenches was practiced. In addition to application in the remediation of burial trenches in the nuclear complex, the system could be very useful in existing civic or commercial sanitary landfills by performing both a reduction in volume and a reduction in leachate.

The In Situ Modular Retrieval and Treatment System is visualized on a scale equivalent to the problem it is intended to address. There are hundreds of acres of landfills to remediate in the DOE complex, and the equipment used to perform that remediation should be capable of performing the task in a reasonable time. Many waste remediation techniques, like grouting or in situ vitrification, are very slow techniques which only remediate a few square feet at a time or require significant set-up time between actual processes. For example, a grouting operation which could treat 50 square feet of waste trenches per hour would be able to treat the Oak Ridge National Laboratory (ORNL) 
trenches in approximately 90 years. The In Situ Modular Retrieval and Treatment System would be able to perform this effort in approximately 5 years. Operational and administrative costs of maintaining a sustained program effort of long duration should be balanced against the high capital costs of this system by comparing the costs of the total program required to process this volume of waste, both in monetary terms and time to compliance.

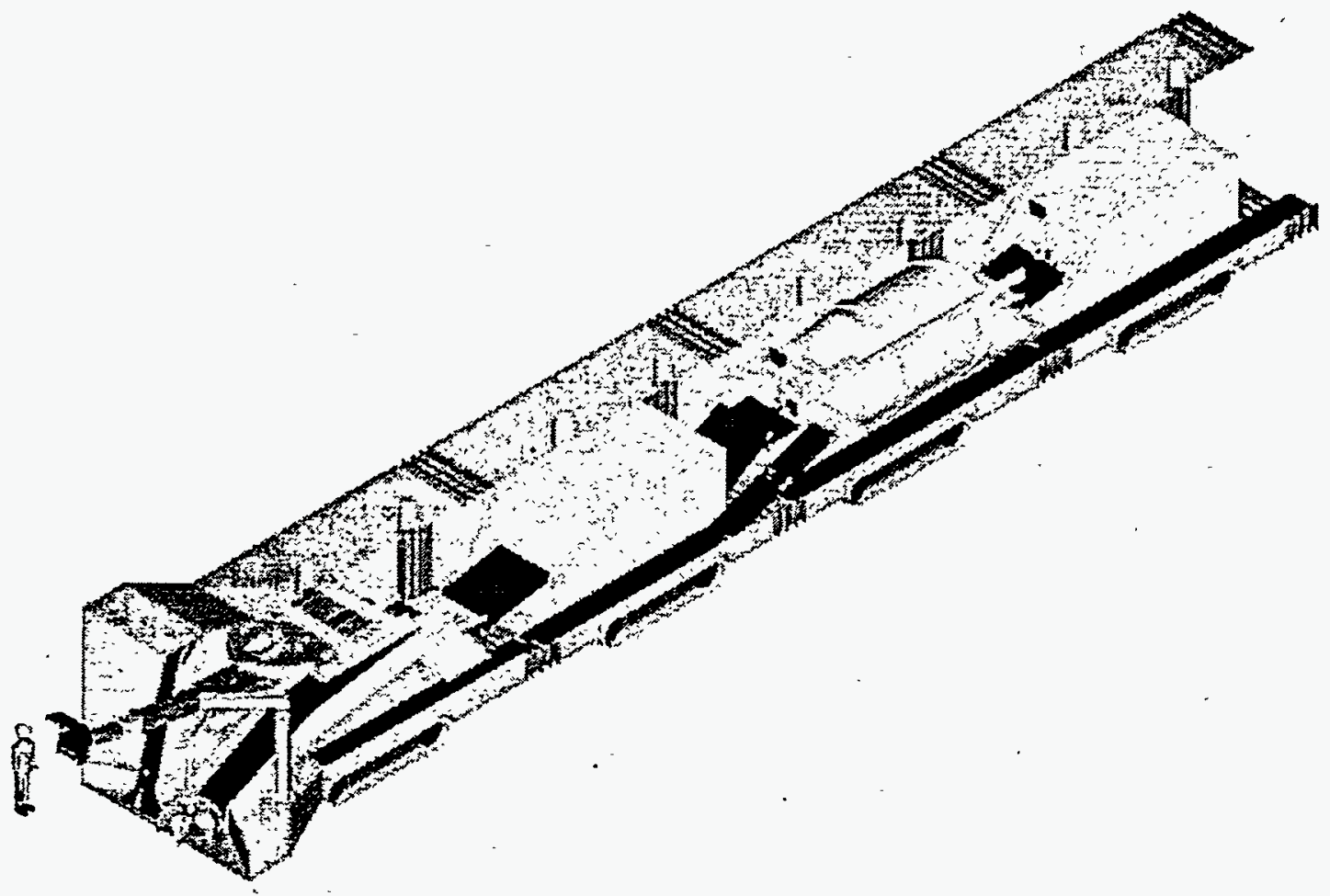

Fig. 1. In Situ Modular Retrieval and Treatment System for shallow buried waste.

\section{CONCEPTUAL DESCRIPTION}

The In Situ Modular Retrieval and Treatment System would consist of multiple modules designed to excavate, shred, and process buried waste on site (Fig. 2). The equipment would be constructed on a scale large enough to excavate and treat entire waste trenches. The operating mechanism would begin at the end of the waste trench and progressively excavate the trench, characterize the waste, classify it, process it, and discharge an acceptable waste form into the former trench location. The waste may then be reburied in place or removed for additional treatment or storage where necessary. Different treatment modules could be designed to handle different types of waste. The system described in this document would be designed for a generalized waste mixture consisting mainly of drums and plastic bags of low-density waste. It would have the capability to deal with larger and denser objects in the trenches by means of physical classification. Following excavation and classification, wastes would be shredded and passed through a low-temperature rotary kiln for incineration, driving off volatiles and burning any paper and plastic wastes, thereby 


\section{OPERATING SEQUENCE}

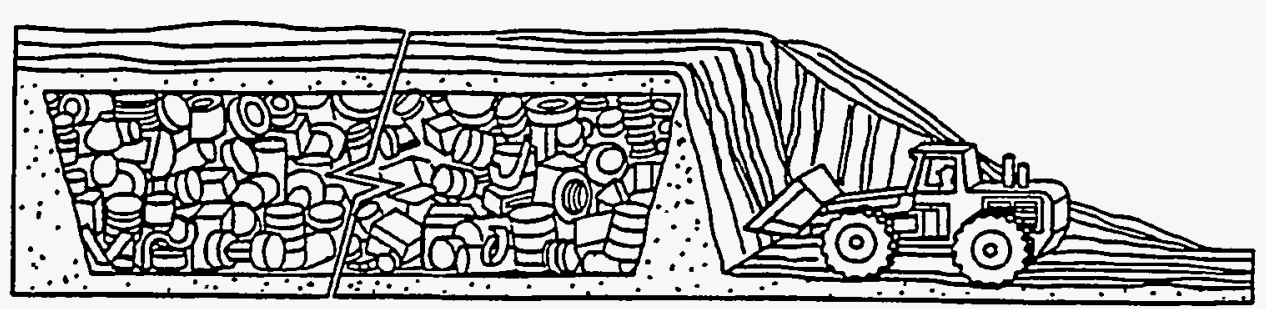

1. TRENCH ACCESS

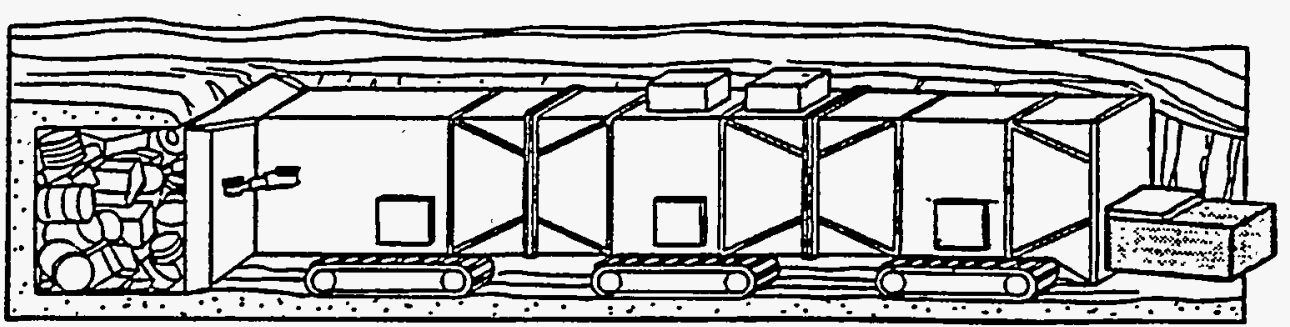

2. WASTE EXCAVATION, SHREDDING, AND TREATMENT

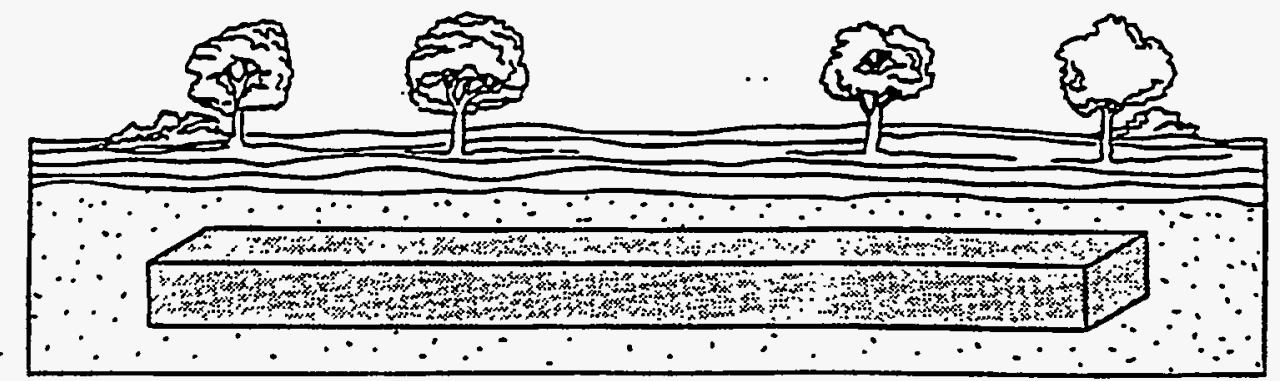

3. STABILIZED WASTE FORM

Fig. 2. Operation sequence of the In Situ Modular Retrieval and Treatment System. 
accomplishing a volume reduction. The final module would bale or compress the incinerated wastes prior to discharge. The wastes would be wrapped in plastic film prior to discharge back into the trench. Additional treatment modules would be defined during the scoping and design phase of the project based on the anticipated waste loadings.

The system would operate on a scale to remediate entire trenches and would be adaptable for site to site variations. The In Situ Modular Retrieval and Treatment System would be capable of performing the remediation of hundreds of acres of landfills in a reasonable time. The treatment modules allow a variety of wastes to be treated and rendered to a form where final disposition would be achieved.

Real-time monitoring of each module would be achieved and with several modules developed would allow for an application of an "observational approach" to the treatment applied. Airborne contamination spread and track out would be minimized by maintaining contact with the entire perimeter of the face of the trench as it is excavated. The equipment would provide containment. All the waste excavation, waste handling, shredding, and treatment operations would be contained within the system, and contamination would not be released nor would workers be exposed.

The technology would have direct application to the private sector in that it would potentially be used to reclaim space in sanitary landfills. Unit treatment modules may or may not be employed depending on the desire of the user. For example, a basic system utilizing the excavation module along with a compactor or baler may be appropriate when only a waste volume reduction is desired.

\subsection{MODULE FEATURES}

The excavation/classification module would accommodate rectangular waste trenches of varying cross sections up to around 10 feet deep by 15 feet wide (Figs. 3 and 4). This would be accomplished by a variable geometry leading edge on the module, which would be forced into the face of the excavation by the advance of the module. The leading edge would act as a seal to prevent airborne contamination of the site. By changing the position of the leading edges, a minimum amount of the surrounding soil burden would be taken in for processing. A bucket type excavator would be used to cut the face of the waste trench away as the module moves forward, in an action similar to soft-earth tunneling machines.

Several classification devices would be used in the excavation/classification module. The excavator bucket would perform the initial removal of waste and move waste items into the front of the module. At that point they might be placed on a conveyor and carried directly to the shredder module, if appropriate. A manipulator would be used to rip open plastic bags, and a vacuum cleaner system would carry loose items such as paper or shoe scuffs and coveralls directly to the shredder. This vacuum system would also be used for general house cleaning in the entry area of the machine. A heavy duty manipulator would be provided for handling small, heavy items that require some dexterity. A grapple would provide still heavier lift capability in the event that a large, heavy item was to be encountered. A bypass conveyor would carry any particularly dense items past the shredder and kiln modules, and in the case of large items, past the baler/wrapper as well. An access hatch would be provided in case an object was to be found that the system would not handle. It should be noted that the shredder would be capable of handling drummed materials without unpacking the drums, and loaded drums would be placed on the conveyor for normal processing. Only solid items which will not shred would bypass the shredder. The manipulator would be capable of piercing drums using nonsparking tools to sample the contents of the drum prior to shredding. Sampling would be conducted on all drums as described below. 


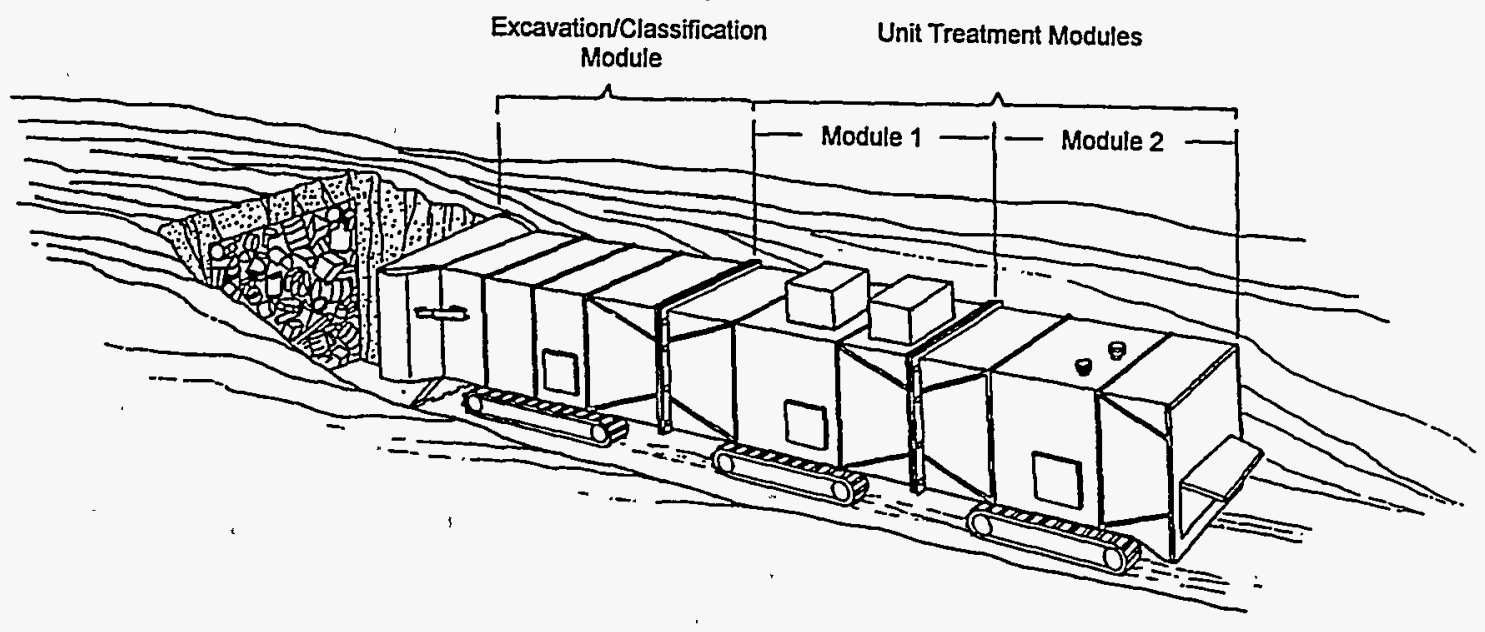

Fig. 3. In Situ Modular Retrieval and Treatment System module arrangement.

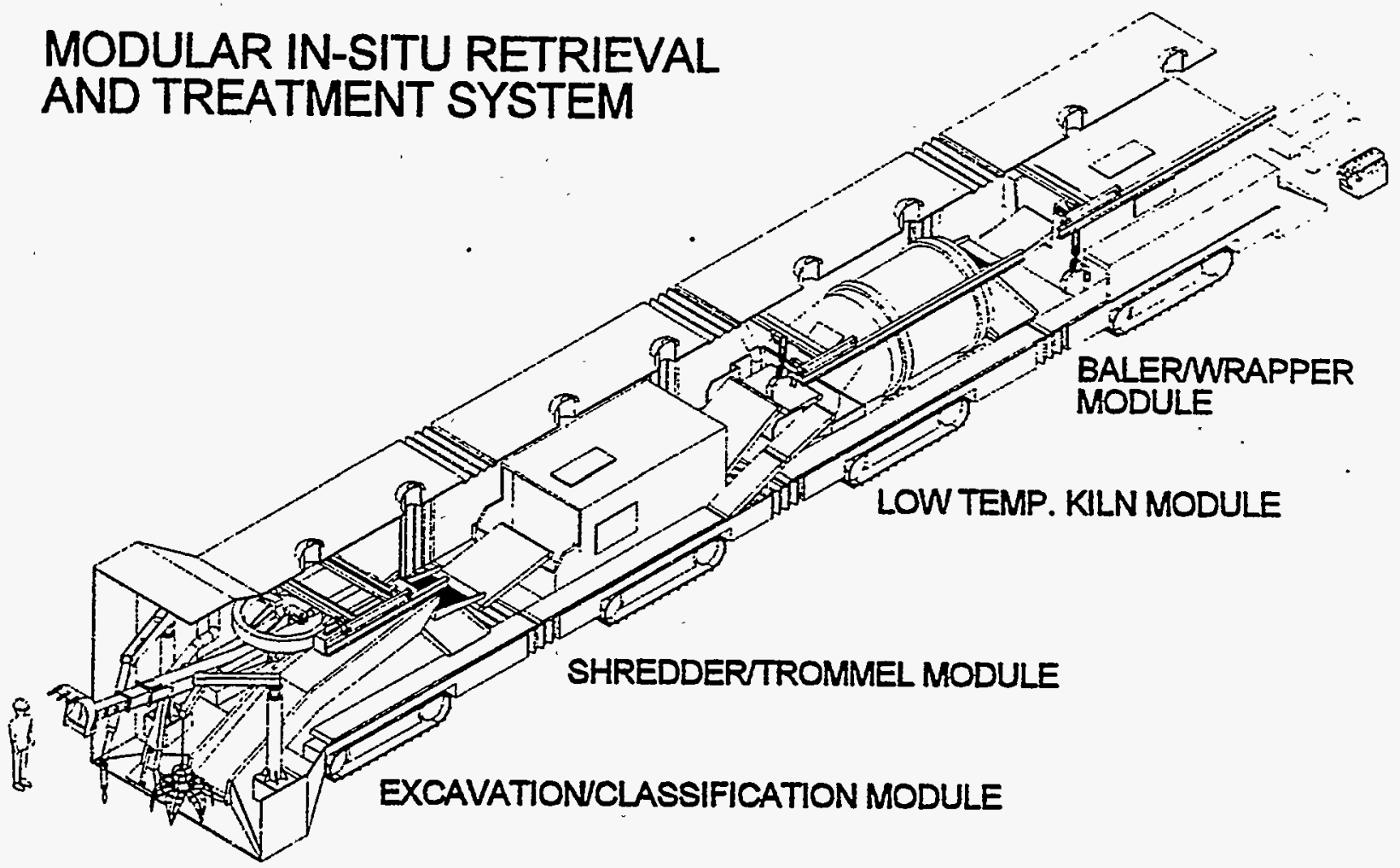

Figure 4. In-situ retrieval and treatment system internal arrangement. 
Monitoring of the operation of the excavation/classification module would include television systems both for observation and telerobotic operation of the equipment. Radiation monitoring would be provided and incorporated into the waste classification protocols. Radioactive materials would be handled in a manner appropriate to the level of contamination measured. Continuous atmospheric monitoring would be conducted in all modules and would also be incorporated into the waste classification protocols. Detection of toxic, explosive, or corrosive gases in the waste stream would determine the operating procedures to be used. Effluent liquids in the trench would be similarly monitored. Air ventilated from the module and any liquids which might be collected would be processed by auxiliary treatment systems.

The shredder/trommel module would be used in the first step of preparing waste for incineration. The waste material would be run across a trommel, which would sort smaller and denser objects from the waste stream prior to the shredder. These objects would be conveyed directly to the bypass conveyor, where they would be carried to the baler/wrapper. Light items and items too large to pass through the trommel would be delivered to a hydraulic shredder. This shredder would be capable of dealing with drums of material and relatively heavy objects, such as pallets, furniture, and appliances. A manipulator or grapple would be provided to clear unshreddable objects from the shredder that might be found inside drums. These objects would be placed on the bypass conveyor. Bypass conveyors would mostly handle items that will not reduce significantly in volume by processing. An access hatch would be provided in case an object was to be found that the system could not handle. All the monitoring provided in the excavation/shredding module would also be necessary in the shredder/trommel module. Air ventilated from the module and any liquids which might be collected would be processed by auxiliary treatment systems.

Following shredding, the waste materials would pass through a low-temperature rotary kiln. Temperature and time in the kiln would be sufficient to ash papers, cloth, fibers, and wood shreds and destroy plastic bags. Water and toxic volatiles would be driven off or broken down in the kiln and the resulting output would be significantly reduced in both volume and leaching potential. A manipulator or grapple would be provided to clear objects which might cause a malfunction or damage to the kiln. These objects would be placed on the bypass conveyor. All the monitoring provided in the excavation/shredding module would also be necessary in the kiln module. Off-gassing from the kiln and air ventilated from the module would be processed by an auxiliary treatment system. Any liquids which might be collected in the module would also be processed by an auxiliary treatment system.

The final module in the group would be a baler/wrapper. The waste stream coming through the rotary kiln would be recombined with the smaller, dense objects not subjected to volume reduction. A manipulator or grapple would be provided to clear objects which might cause a malfunction or damage to the baler/wrapper. The mix would be compacted or baled and then wrapped in polyethylene prior to ejection from the modules. Large dense objects would simply be ejected for separate disposition and disposal. All the monitoring provided in the excavation/shredding module would also be necessary in the baler/wrapper module. Air ventilated from the module and any liquids which might be collected would be processed by auxiliary treatment systems.

\subsection{AUXILIARY EQUIPMENT}

The equipment discussed thus far and shown in the figures would be supported by a great deal of portable auxiliary equipment which would be located adjacent to the waste trenches. An off-gas treatment plant would be required to process not only the effluent of the kiln but also gases generated in all the modules. A treatment plant would also be required to process liquid effluent. In addition, 
a vehicle would be required for telerobotic control of some equipment, for control of the operation of the various processes and for monitoring and recording instrument outputs. Because of the location of the waste trenches, it would be likely that portable electric power plant would be required. Hydraulic power units would also be required for the shredder and perhaps for the module drive motors if hydraulic drive was to be selected. A portable automated analytical laboratory would provide fast turn-around analysis of unknowns from the waste stream and would enable optimum utilization of the system.

Additional support equipment required would include conventional excavation equipment for various tasks. The soil overburden from the waste trench must be removed from the top of the modules and kept for later return to the trench. The modules would be reinforced so that this would be done using conventional small-skid steer loaders. A system must be developed for shoring up the sides of the trench to prevent slides from encroaching on the modules as they move forward. Best practices would be used for management of environmental concerns for the open excavations, until such time as they may be refilled and remediated.

\section{TECHNOLOGY REQUIREMENTS}

\subsection{EXISTING TECHNOLOGIES}

The modules would be built on similar crawler/dozer chassis and would utilize commercially available drive systems whenever practical. The drive systems would require some modifications to the cooling systems, for example, because of the operation in the bottom of a trench where air flow would be restricted. The location of the motor and transmission in a conventional crawler/dozer drive train might interfere with the material flow or the internal equipment of the modules. Hydraulic wheel motors might be a more practical choice than a conventional crawler/dozer chassis, as the entire drive unit would be placed on the top of the module. The drive unit might be designed for removal during transportation. This would also provide maintenance advantages by providing better access to the drive unit and by moving it out of the area where it would be most likely to be contaminated during operation.

The mechanical construction of the modules would be conventional in terms of excavation equipment, but a significant area of difference between the mechanical construction of this equipment and conventional earth moving equipment is the need to accommodate decontamination. The equipment would be designed not only to facilitate decontamination but also to prevent contamination from being trapped in operation. Remote decontamination and maintenance would not be required in most cases, however, it should be designed into the system if needed. The decision to incorporate remote maintenance and decontamination must be made early in the project, as costs for this capability would be high. Adding the capability late in the design cycle would, however, be even more costly.

Systems monitoring for preventive maintenance would be provided to afford a substantial cost savings once the equipment becomes operational. Lost production time for remediation activities, as well as savings in direct costs of maintenance, would be significantly reduced with monitoring.

The excavation/classification module would accommodate rectangular waste trenches of varying cross sections up to around 10 feet deep by 15 feet wide. This would be accomplished by a variable geometry leading edge on the module, which would be forced into the face of the excavation by the 
advance of the module. The leading edges would be hydraulically actuated and would be adjusted based on the waste cross section as observed through a cable television system. If high concentrations of volatile organic compounds were to be detected by monitoring instruments, the leading edges may also be adjusted to accommodate a contaminate soil waste cross section not otherwise visible on the CATV system. The bucket type excavator would be of conventional design, modified for telerobotic use, as has been demonstrated at several DOE sites. The transport conveyor and the bypass conveyors would be of conventional heavy duty soil conveyor design. The vacuum cleaner system would require a new design to incorporate telerobotic operations, to include a ripper to open plastic bags, and to assure that the plastic bags would not clog the vacuum system. The heavy duty manipulator would be a commercially available hydraulic unit, such as those sold by Schilling Robotics. The grapple would incorporate telerobotic operation and would include the "swing free" lifting technology recently demonstrated at ORNL.

The shredder/trommel module would be largely based on commercial equipment. Trommels are widely used in conventional soil remediation, and large hydraulic shredders are used in many industries for materials recycling. Many of the monitoring and control technologies discussed for the excavation/classification module would also be necessary in the shredder/trommel module. The control system for the manipulator or grapple in this unit would require similar controls to the excavation/classification module manipulator or grapple.

The low-temperature rotary kiln would be very similar to units used in commercial soil remediation work. Many of the monitoring and control technologies provided in the excavation/classification module would also be necessary in the kiln module. The control system for the manipulator or grapple in this unit would also require similar controls to the excavation/classification module manipulator or grapple.

The baler/wrapper would also be based largely on available commercial equipment, and again, many of the monitoring and control technologies provided in the excavation/shredding module would also be necessary in the baler/wrapper module. The control system for the manipulator or grapple in this unit would also require similar controls to the excavation/classification module manipulator or grapple.

The equipment discussed thus far and shown in the figures would be supported by a great deal of mobile auxiliary equipment, which would be located adjacent to the waste trenches. The support equipment would utilize commercially available chassis and drive systems whenever practical and be designed for over-the-road transport.

An off-gas treatment plant would be required to process not only the effluent of the kiln but also gases generated in all the modules. A liquid treatment plant would also be required to process effluent. These systems may be very sophisticated depending on the anticipated toxic and radiological characteristics of the anticipated wastes, or they may be commercially available soil- and water-remediation units and emission control systems. The most significant technical challenge would be reducing the size and placing these plants on mobile platforms without reducing throughput to a point that limits the overall production rate of the entire system.

A commercial portable electric power plant and commercial hydraulic power units would also be required.

A portable automated analytical laboratory to evaluate and analyze soil, smear, effluent, and air samples would provide fast turn-around analysis of unknowns from the waste stream and would enable optimum utilization of the system. This laboratory might be based on the technology being 
developed at Idaho National Engineering Laboratory (INEL) for the field deployable Rapid Transuranic Monitoring Laboratory. Other candidate technologies which may contribute to the analytical capabilities of the laboratory are the Contaminant Analysis Automation and Standard Analytical Modules being developed at Los Alamos National Laboratory. All these support systems would be equipped with telemetry for central data collection.

Most of the additional support equipment required would be commercially available excavation equipment, such as small-skid steer loaders and front-end loaders. The system developed for shoring up the sides of the trench would be similar to standard shoring systems, except that they would be anchored outside the trench instead of using internal bracing. This would be a relatively straightforward design and development job. Other runoff and pollution abatement practices would also be required, consistent with the best available practices for operation of landfills.

\subsection{TECHNOLOGY NEEDS}

All the modules would be telerobotically operated. The technology for telerobotic control of large earth-moving equipment has been demonstrated at several DOE sites. The modules would be linked together electronically and would be designed for control as individual modules as well as an integrated train. This would require the development of a fully integrated control system with the flexibility to adapt to various module types, including future modules of types as of yet undetermined. The Graphics-Based Robotics Control technologies being developed at Sandia National Laboratories (SNL) may provide a good starting point for this system.

Monitoring of the operation of all the modules would include television systems both for observation and telerobotic operation of the equipment. This seems to be a very good candidate for a virtual reality-based control environment. The Graphics-Based Robotics Control technologies being developed at SNL may be very useful for this interface as well.

Waste monitoring technologies are currently being developed as part of the Dig-Face Characterization Project of the Mixed Radioactive/Hazardous Waste Working Team. Radiation monitoring equipment would include both commercially available equipment and the passive gamma ray spectroscopy system being developed at INEL for assay of soils with potential transuranic waste contamination. Continuous atmospheric and effluent monitoring equipment would include commercially available equipment along with the imaging infrared interferometer technology developed at INEL for volatile organic compounds.

A control vehicle would be required for telerobotic operation of the various processes and for monitoring and recording instrument outputs. This unit might include the system health monitoring technology for hydraulic, mechanical, and electrical systems now being developed at INEL. As mentioned above, this seems to be a very good candidate for a virtual reality-based control environment or for the Graphics-Based Robotics Control technologies being developed at SNL. 


\section{EVALUATION}

\subsection{POTENTIAL BENEFITS}

The In Situ Modular Retrieval and Treatment System would able to excavate, shred, and process buried waste on site, with minimum disturbance and distribution of dust and debris into the air. Airborne contamination spread and track out would be minimized by maintaining contact with the entire perimeter of the face of the trench as it is excavated. The system would characterize and process waste as it is encountered. The result would be a substantial reduction of the volume of the wastes as well as the elimination of most of its volatile contents. The system would have immediate application in areas wherever systematic burial in fairly consistently sized long trenches was practiced. The system could be very useful in existing civic or commercial sanitary landfills by performing both a reduction in volume and a reduction in leaching of volatiles. The processed waste would be encapsulated and left in place in the trench or moved to a more appropriate site.

The In Situ Modular Retrieval and Treatment System technology would be suitable to most of the buried waste trenches at DOE sites. It would also be highly suited for private sector hazardous waste remediation and reduction. This equipment would be based on currently existing technologies and would utilize others now under development in the BWD and other DOE projects. It would also be applicable for use in municipal and other sanitary landfills which are approaching capacity. In this application, the primary benefits would be reduction of waste volume and remediation of facilities built to obsolete standards by encapsulation of the waste and subsequent reduction of leaching and production of methane and other volatiles.

The system would be adaptable for site-to-site variations. The modular treatment modules would allow a variety of wastes to be treated and rendered to a form where final disposition would be achieved. The use of real-time monitoring of each module and real-time dig face characterization would facilitate the waste treatment methods applied and the modules that might be deployed. In other words, treatment modules may or may not be employed depending on the waste characteristics observed at the dig face. For example, if the system were to be used to reclaim space in sanitary landfills, a basic system utilizing the excavation module along with a compactor or baler would be appropriate if only a waste volume reduction were desired.

\subsection{LIMITATIONS}

Perhaps the most important limitation to this technology is the size of the equipment involved. The treatment modules themselves would typically be a train over one hundred feet long when deployed into the trench. This train would be supported by a fleet of auxiliary equipment of approximately equal size, which must be as close as practical to the trench excavation. This places some significant limitations on the size and topology of the sites which would be treatable using this technology. It would be possible to use temporary conveyors or other material-handling equipment to move the waste from one module to the next until there was room in the trench to connect the modules directly.

Additionally, the geometry of the modules would require that the waste trenches be relatively straight. The joints between modules would provide some flexibility, but the system would not accommodate tight radius curves in the trenches. 
Another issue associated with the limited flexibility of the system is that of deployment. Once the face of the waste trench is exposed, the train of modules must be placed in line before proceeding if a totally integrated system is necessary. Since treatment modules may or may not be employed depending on the waste characteristics observed at the dig face, it might be necessary to change the modules that have been deployed, based on the use of real-time monitoring of each module and real-time dig-face characterization. This change-out would be a time-consuming operation. It may be possible to stage the modules so that each would be placed into the line as the excavation proceeds, but the waste would have to be handled by other means until the entire train is assembled. It would also be possible to use temporary conveyors or other material-handling equipment to move the waste to the correct module temporarily if the change in waste content were to be determined to be very localized.

A difficulty exists in handling potentially explosive materials. For example, drummed fuels or solvents may be encountered in the waste. If not adequately identified, the potential for an explosion or fire would be very real when the drum is pierced during handling or in the shredder. This could result in at least damage to equipment and at worst a release of hazardous materials. While current technologies exist for the detection of explosive or flammable volatiles in air and waste materials, the problem of "hidden" explosive materials may require additional exploration. As mentioned earlier, nonsparking tools would be provided to pierce drums for sampling prior to shredding, but it cannot expected that the explosion hazard would be entirely eliminated. This problem is not unique to this system and must be addressed by any waste excavation technology.

\subsection{ROUGH DEVELOPMENT COST AND SCHEDULE}

A conceptual timetable and estimated budget for this project is included in Table 1. The estimated cost of this project is largely based on doing much of the development work for candidate technologies within the scope of this project. If the candidate technology projects are funded independently as either stand-alone projects or as a part of other programs, a considerable savings over this estimate would be anticipated. An opportunity for cost sharing is also available when more than one major project identifies the need for a given technology, and funding is used cooperatively.

Table 1. Modular In Situ Retrieval and Treatment System preliminary work plan and budget estimate

\begin{tabular}{lcccc}
\hline \multicolumn{1}{c}{ Job Element Description } & Start Date & End Date & Duration (yrs) & Cost Estimate \\
\hline $\begin{array}{l}\text { Develop Preliminary Functional } \\
\text { Specification }\end{array}$ & FY-1995 & FY-1996 & 1 & $\$ 100,000$ \\
$\begin{array}{l}\text { Develop Systems Requirements } \\
\text { Document }\end{array}$ & FY-1996 & FY-1997 & 2 & $\$ 1,100,000$ \\
$\begin{array}{l}\text { Evaluate Candidate Excavation } \\
\text { Technologies }\end{array}$ & FY-1996 & FY-1997 & 2 & $\$ 350,000$ \\
$\begin{array}{l}\text { Evaluate Candidate Shredding } \\
\text { Technologies }\end{array}$ & FY-1996 & FY-1997 & 2 & $\$ 350,000$ \\
$\begin{array}{l}\text { Evaluate Candidate Incineration } \\
\text { Technologies }\end{array}$ & FY-1996 & FY-1997 & 2 & $\$ 700,000$ \\
$\begin{array}{l}\text { Evaluate Candidate } \\
\text { Compactor/Baler Technologies }\end{array}$ & FY-1996 & FY-1997 & 2 & $\$ 350,000$
\end{tabular}


Table 1 (continued)

\begin{tabular}{lcccc}
\hline \multicolumn{1}{c}{ Job Element Description } & Start Date & End Date & Duration (yrs) & Cost Estimate \\
\hline $\begin{array}{l}\text { Evaluate Telerobotic Material } \\
\text { Handling Technologies }\end{array}$ & FY-1996 & FY-1997 & 2 & $\$ 700,000$ \\
$\begin{array}{l}\text { Evaluate Telerobotic Control } \\
\text { Systems Technologies }\end{array}$ & FY-1996 & FY-1997 & 2 & $\$ 1,400,000$ \\
$\begin{array}{l}\text { Evaluate Module Chassis/Drive } \\
\text { Systems }\end{array}$ & FY-1996 & FY-1997 & $: 2$ & $\$ 700,000$ \\
$\begin{array}{l}\text { Evaluate Off-gas Treatment } \\
\text { Technologies }\end{array}$ & FY-1996 & FY-1997 & 2 & $\$ 2,100,000$ \\
$\begin{array}{l}\text { Evaluate Liquid Effluent } \\
\text { Treatment Technologies }\end{array}$ & FY-1996 & FY-1997 & 2 & $\$ 1,400,000$ \\
$\begin{array}{l}\text { Evaluate Portable Analytic } \\
\text { Laboratory Technologies }\end{array}$ & FY-1996 & FY-1997 & 2 & $\$ 350,000$ \\
$\begin{array}{l}\text { Selection of Candidates and } \\
\text { Initiation of Preliminary Design }\end{array}$ & FY-1997 & FY-1998 & 1 & $\$ 1,400,000$ \\
$\begin{array}{l}\text { Preliminary System Integration } \\
\text { Prototype Design }\end{array}$ & FY-1997 & FY-1998 & 2 & $\$ 1,400,000$ \\
\begin{tabular}{l} 
Prototype Fabrication and Testing \\
\hline \hline Total Cost thru Prototype
\end{tabular} & FY-1998 & FY-1999 & 2 & $\$ 7,000,000$ \\
\hline & FY-1995 & FY-2002 & 7 & $\$ 139,400,000$ \\
\hline
\end{tabular}

\subsection{COST/BENEFIT}

The estimated expenditure to develop the In Situ Modular Retrieval and Treatment System is $\$ 139,400,000$, from Table $1^{\circ}$, making the assumptions as stated in Sect. 5.3. The unit cost of processing waste is tabulated below.

Cubic yards of waste per hour $(15 \mathrm{ft} \times 20 \mathrm{ft} \times 4 \mathrm{fthour})$

Hours available per year

Cubic yards of waste per year

66,660

Annual direct labor, assuming 20 workers (hours)

4,1600

Annual labor costs ( $\$ 80.00 /$ hour $)$

$3,328,000$

Annual Materials and Maintenance Charges (\$)

$10,000,000$

Annual Equipment Cost, Assuming 5-year life (\$)

$27,880,000$

Total Annual Cost

$41,208,000$

Unit Cost \$/cubic yard

618.18 
While this estimated unit cost is not competitive with other buried waste remediation technologies, the In Situ Modular Waste Retrieval and Treatment System has the capacity to remediate hundreds of acres of landfills in the DOE complex in a reasonable time. Thus, this system should be evaluated in the context of the total costs, both in monetary terms and time to compliance, by comparison with the cost of sustaining programs using other technologies for very long durations or with the cost of using large numbers of other systems to achieve similar throughput. In addition, the In Situ Modular Waste Retrieval and Treatment System is adaptable to use in a number of configurations and at many sites, while technologies such as those being developed for INEL's Pit 9 are suitable only to limited and very specific tasks, and once those tasks are completed, the equipment would not be suited for any other use. The In Situ Modular Retrieval and Treatment System would able to excavate, shred, and process buried waste on site, with minimum disturbance and distribution of dust and debris into the air. The system would characterize and process waste as it might be encountered. There would be a reduction of waste volume and elimination of most of the waste's volatile contents. The processed waste would be encapsulated and left in place in the trench or moved to a more appropriate site. The system would be adaptable for site-to-site variations since the modular treatment modules allow a variety of wastes to be treated.

The unit cost of operating the In Situ Modular Retrieval and Treatment System listed above assumes a conservative 5-year life for the equipment and a conservative materials and maintenance charge, due to decontamination issues. It also assumes that only one unit would absorb all the development costs. If the useful life were to be 10 years and maintenance charges were cut by $50 \%$ (which is likely to be the case in most low-level radiation and municipal operations) and if a second unit were built at $75 \%$ of the cost of fabrication and testing of the first prototype, unit costs on the order of $\$ 300 /$ cubic yard could be achieved. As mentioned earlier, if the some or all of the candidate technology projects are funded independently as either stand-alone projects or as a part of other programs, a considerable savings over this estimate would be anticipated. An opportunity for cost sharing is also available when more than one major project identifies the need for a given technology and funding is used cooperatively. While the In Situ Modular Retrieval and Treatment System would require a very substantial capital investment, it could be very competitive with current remediation costs and would achieve remediation at a rate beyond any current means.

\section{CONCLUSIONS}

The In Situ Modular Retrieval and Treatment System is a technically feasible approach to the remediation of current trench waste burial sites for all types of solid wastes and other waste forms that can be excavated, such as drummed liquids and gas cylinders. The technologies to be used in the proposed system are either currently available or under development.

More work is required to evaluate alternate configurations that overcome some of the deployment difficulties discussed earlier and to further incorporate technologies under development commercially and in other programs.

While the estimated unit cost for the first prototype is not competitive with other buried waste remediation technologies, the In Situ Modular Waste Retrieval and Treatment System is designed to meet the challenge of hundreds of acres of landfills to remediate in the DOE complex in a reasonable time frame. This system should be evaluated in the context of the total costs, both in monetary terms and time to compliance, by comparison with the cost of sustaining programs using other technologies for very long durations or with the cost of using large numbers of other systems 
to achieve similar throughput. In addition, the In Situ Modular Waste Retrieval and Treatment System would be adaptable to use in a number of configurations and at many sites, while other technologies are suitable only to limited and very specific tasks, and once those tasks are completed, the equipment would not be suited for any other use.

\section{RECOMMENDATIONS}

The In Situ Modular Retrieval and Treatment System would be an attractive method of processing buried wastes. While technically feasible, the In Situ Modular Retrieval and Treatment System would be costly, and a recommendation to proceed should be preceded by a thorough evaluation against the alternatives.

The work performed to date on the project has been very preliminary. The conceptual design presented in this report has some significant limitations. Additional conceptual design work should be performed in overcoming the identified problems. The effort should focus on four major areas:

- design and fabrication of an excavation/shredding module,

- development of unit treatment operation modules,

- real-time monitoring of waste as it travels through the unit treatment processes, and

- real-time treatment of off-gassing and liquid effluent produced as a result of the In Situ treatment process.

In addition, a concept where only the excavation module enters the trench seems to be an obvious approach to resolving the deployment and flexibility problems, allowing the use of the modular waste in situ retrieval and treatment system in shorter and more curved waste trenches. In this concept, all the rest of the equipment would be along side the trench with the other auxiliaries, and the encapsulated wastes could be returned to the trench by conventional material handling equipment prior to back filling. Other alternative configurations should also be evaluated.

As a part of this process, a systems requirements document should be prepared for the system, and the candidate technologies should be further evaluated and preliminary selections made in preparation of beginning a preliminary design. As part of the preliminary design a detailed cost estimate should be made and an economic analysis and comparison of the In Situ Modular Retrieval and Treatment System as well alternative technologies should be done. The scope of the project should be expanded enough to insure a multidiscipline approach and to assure that input and participation of all interested parties is facilitated. 
Appendix

IN SITU MODULAR RETRIEVAL AND TREATMENT SYSTEM VENDOR AND TECHNOLOGY SOURCE LIST 

This listing represents a partial list of sources for technologies applicable to the In Situ Modular Retrieval and Treatment System. It has been gathered from public literature and is by no means comprehensive and complete. It is merely a representative sample of the available technologies at this time.

Table A.1. In Situ Modular Retrieval and Treatment Systems vendor and technology source list

\begin{tabular}{cl}
\hline Vendor & Technology \\
\hline
\end{tabular}

Applied Radiological Control

Kennesaw, GA

(404) 429-1188

Shred-Tech Corp.

Cambridge, ON Canada

(800)465-3214

Slidell Corp.

Owatonna, MN

(800) 328-1769

Geophysical Survey Systems, Inc.

North Salem, NH

(800)524-3011

Thermotech Systems

Orlando, FL

(404) $290-6000$

Soil Purification, Inc.

Chattanooga, TN

(709) 861-0069

Soil Washing Technologies

Salisbury, MD

(410) $860-2947$

Tarmac Equipment Co., Inc.

Soils Division

Blue Springs, MO

(800) 833-4383

Finch Environmental Corp.

West Pittston, PA

(717)655-2277

GenTec Environmental

Louisville, $\mathrm{KY}$

(800) 826-0223

Clearfield Companies, Inc.

Clearfield, UT

(801)773-8608

Harris Waste Management Group

Peachtree City, GA

(404) 631-7290
Mobile chemistry and counting laboratories

and specialty decontamination and cleaning

Shredders for municipal and hazardous wastes and recycling

Automatic bagging systems and conveying systems

Subsurface Interface Radar surveying equipment

Thermal soil remediation, including mobile systems

Thermal soil remediation, including mobile systems

Chemical soil washing, including mobile systems. Effective on hydrocarbons and heavy metals

Soil remediation systems, including mobile systems

Rotary incinerators and trommels

Soil processing equipment, including kilns, dryers, feeders, bag houses, and scrubbers

Waste compactors and drum crushers

Waste balers, shears, and waste transfer systems 
Table A.1 (continued)

Donovan Enterprises

Stuart, FL

(800) $327-8287$

Gensco America, Inc.

Lithonia, GA

(404) 482-4486

Walker National, Inc.

Columbus, $\mathrm{OH}$

(614) 481-0007

Enviroscan

Rothschild, WI

(800) 338-7226

Purgo, Inc.

Richmond, VA

(800) 446-2614

FERtech Enviro Systems, Inc.

Moberly, MO

(800) $362-8808$

Griffolyn Division, Reef Industries

Houston, TX

(800) 231-6074

ThermTech, Inc.

Kingswood, TX

(800) 659-8271

CleanSoil

West Columbia, SC

(803) 796-1644

Environmental Instruments

Concord, CA

(800) 648-9355

Site Reclamation Systems, Inc.

Tavares, FL

(904) $343-1715$

Alternative Remedial Technologies Tampa, FL

(813) $264-35$

Covertech Fabricating, Inc.

Otibicoke, Ontario

(416) 798-1342
Hazardous waste container bag liners

Hydraulic grapples

Magnetic scrap handling equipment

Mobile laboratory for soil and groundwater services

Thermal soil remediation, including mobile systems. Rotary kilns and oxidizers

Thermal soil remediation, including mobile systems

Contaminated soil covers

Thermal and catalytic oxidizers, including mobile systems

Steam soil cleaning, including mobile systems. Rotary kilns and oxidizers

Thermal oxidizers, including mobile systems

Thermal soil remediation, including mobile systems

Soil washing systems, including mobile systems

Contaminated soil covers 
Table A.1 (continued)

Buried Waste Integrated Demonstration DOE

Washington, DC

(301)903-7965

Robotics Technology Development

Program

DOE Office of Environmental

Management, Office of Technology

Development

Washington, DC

(301) 903-7293

Mixed Radioactive/Hazardous Waste

Working Group

Western Governors' Assoc.

DOE, U.S. Department of Defense,

U.S. Department of the Interior, U.S.

Environmental Protection Agency (EPA)

(208) 526-6249
- Contaminated Material Excavation Handling and Retrieval System (Pacific Northwest Laboratory)

- Full-scale remotely operated excavator (INEL)

- Computer-generated virtual environment for buried waste sites (INEL)

- System health monitoring for remotely operated hydraulic, mechanical, and electrical equipment (INEL)

- Imaging infrared interferometer for stand-off site characterization and detection of volatile organic compounds and toxic gases (INEL)

- Rapid transuranic monitoring laboratory (INEL)

- Many other technologies are also available through the BWID Project

- Robotics contaminant analysis automation of on-site sample analysis [Los Alamos National Laboratory (LANL)]

- Standard laboratory module and standard analysis method (LANL)

- Automated work cell model updating (SNL/SRTC)

- Remote waste characterization and sorting [Lawrence Livermore National Laboratory (LLNL)]

- Swing-free crane control (SNL/ORNL)

- Autonomous modeling and grasping of waste items (LLNL/SRTC/ORNL)

- Robotics system simulation and graphics-based robot control (SNL)

- Many other technologies are also available through the Robotics Technology Development Program

- Dig-face characterization (INEL)

- Advanced landfill cover demonstration (SNL/LANL/EPA)

- Two-stage advanced mobile oxidation/reduction unit for mixed waste treatment (LANL/INEL/Electric Power Research Institute)

- Many other technologies are also available through the Mixed Radioactive/Hazardous Waste Working Group 


\section{DISTRIBUTION}

1. L. V. Asplund

2. W. D. Brickeen

3. K. W. Cook

4. D. G. Garrett

5. L. C. Hensley

6. C. M. Kendrick

7. A. J. Kuhaida, Jr.

8. D. M. Matteo

9. P. T. Owen

10. P. A. Schrandt

11. J. Trabalka

12. S. D. VanHoesen

13. Central Research Library

14. ER Doc. Mgmt. Center-RC

15-16. Office of Scientific and Technical Information, P.O. Box 62, Oak Ridge, TN 37831 (2)

17. W. D. Bouten, P2 Technologies, P.O. Box 22668, Knoxville, TN 37933

18. M. Carroll, Machine Kenetics Corporation, P.O. Box 50635, Knoxville, TN 37950-0635

19. E. R. Cox, DOE/OS, Room 700N, 1301 Clay Street, Oakland, CA 94612-5208

20. B. Creighton, WETO, P.O. Box 3767, Butte, MT 59702

21. G. Huffman, RFS, Building T116, P.O. Box 928, Golden, CO 80402-0928

22-24. J. W. Kubarewicz, Jacobs Engineering, 125 Broadway Avenue, Oak Ridge, TN 37830 (3)

25. W. LaVeille, SRS, Building 703-A, P.O. Box A, Aiden, SC 29802

26. K. Lowe, RFS/ORNL, Building T124A, P.O. Box 928, Golden, CO 80402-0928

27. S. McMullin, DOE/SRS, P.O. Box A, Building 703-A, Aiken, SC 29802

28. P. Moskowitz, Brookhaven National Lab., Building 830, Upton, NY 11973

29. D. Nickelson, INEL LITCO, P.O. Box 1625, Idaho Falls, ID 83415-3710

30. C. O'Laughlin, NTS, P.O. Box 93518, Las Vegas, NV 39193-3518

31. D. Pflug, Chicago Site, EAD/900, 9700 South Cass Avenue, Argonne, IL 60439-4832

32. M. Serrato, SRTC, P.O. Box A, Building 703-A, Aiken, SC 29802

33. R. Shank, SRS/WSRC, Building 730-2B, Room 1035, P.O. Box 616, Aiken, SC 29808

34. M. S. Walker, Aegis, 749 Blockhouse Road, Clinton, TN 37216 